\title{
West Africa: \\ From Peacekeeping to Peace Enforcement. ECOWAS and the Regulations of Regional Security
}

\author{
Uchechukwu Johnson AGBO \\ Nsemba Edward LENSHIE \\ Raji Rafiu BOYE
} \begin{abstract}
major goals of ECOWAS, has engaged in several peacekeeping operations. However, the nature of the conflict from these states rendered peacekeeping operations inadequate, leading to the adoption of peace enforcement as a new mechanism for mitigating intractable conflicts in West Africa. It is in this context that this article investigates the role of ECOWAS in peacekeeping operations and its transformation to peace enforcement in the West African security complexes.
\end{abstract}

Abstract. The ECOWAS principle of non-interference in the internal affairs of member states included in its Charter was in line with the sovereignty of states in the international system. This principle, ECOWAS, has to some extent been kept, but the growing insecurity arising from internal conflicts in West Africa states motivated the adoption of ECOMOG as a mechanism for peace and security. The ECOMOG, in the effort to securitize the region to enable economic integration and development as

Keywords: peacekeeping, peace enforcement, conflict, peace and security, West Africa.

\section{Introduction}

The Economic Community of West African States (ECOWAS) was mainly formed based on the objective of economic integration and development, but not without political undertones. The idea of forming ECOWAS
Uchechukwu Johnson AGBO, Ph.D

Department of Political Science,

Federal University Wukari, Nigeria

Email: agbojohnson@gmail.com

Nsemba Edward LENSHIE

Department of Political Science

and International Relations,

Taraba State University, Jalingo, Nigeria

Email: edward.lenshie@tsuniversity.edu.ng

Raji Rafiu BOYE

Department of Political Science,

Yobe State University, Damaturu, Nigeria

Email: brajirafiu@yahoomail.com

Conflict Studies Quarterly

Issue 22, January 2018, pp. 18-35

DOI:10.24193/csq.22.2

Published First Online: 01/10/2018 
dates back to 1964 when the late Liberian President William Tubman first made a proposal for the need of having a union to promote economic integration and development in West Africa. This attempt brought Cote d'Ivoire, Guinea, Liberia and Sierra Leone into signing the agreement in 1965. The aspiration could not produce meaningful results until in 1972 when the late President Gnesigba Eyedema of Togolese Republic and General Yakubu Gowon of Federal Republic of Nigeria decided to tour 12 countries in the region in support of the idea of integrating the West African economies and monetary policy. By 28 May 1975, fifteen West African countries signed the treaty that established ECOWAS in Lagos, Nigeria. The protocols that led to the inauguration of ECOWAS were signed in Lome, Togo, on 5 November 1976 (Malu, 2009; Okere, 2015).

Since 1975, the twin concepts of economic integration and development in West Africa have been the guiding principles of ECOWAS, though the economic integration has been emphasized more than security regulations. Indeed, without peace and security, no economic development can thrive. As Olukoshi (2001) observed, establishing the supranational organisation to generate rapid growth and development in West Africa, was based on the assumption of providing a stable and secure environment for integrating economies. Achieving the task of economic integration and development has remained difficult to attain as a result of political instability and recurrent conflicts in West Africa as responses to the bad, corrupt and weak institutional governance. The unstable nature of the sub region compelled ECOWAS to go beyond the goals of economic integration and development to include peace and security as essential requirements to achieve those goals (Bah, 2004). The ECOWAS intervention in some of the internal conflicts in the member states was as a result of the failure of internal institutional mechanism put in place to regulate security governance. This led to violent conflicts of a higher magnitude that called for extra-national solution.

The need for ECOWAS also coincided with an era in the history of Africa when most states lost legitimacy due to enormous pressure capitalist centres with their unfriendly economic policies have had on the subregion. It was also an era when the powers that are at the international level that regulates security issues were fatigued with or not interested in African conflicts. These challenges reinforced the need for an African solution to what was largely perceived as an African problem by United Nations and those in control of global governance (Khobe, 2000). In this light, the most important ECOWAS institution, the "Authority of the Head of States and Government" was mobilized by the then Chairman of ECOWAS Head of States and Government, President Dauda Jawara, to devise the modalities of ending the Liberian conflict and to determine the probable effects that the conflict was going to have on West Africa. An emergency summit was convened in Banjul, Gambia, where the Head of states and Government of ECOWAS met and devised the way out of the Liberian conflict. The outcome of the summit was the establishment of a Standing Mediation Committee (SMC) comprising Ghana, Mali, Gambia, Togo and Nigeria (Birikorang, 2013; Malu, 2009). 
The Committee decided that ECOWAS should establish, under the Authority of Head of States and Government of ECOWAS member States, a Cease-Fire Monitoring Observer Group (ECOMOG) to be composed of military contingents drawn from member States of the SMC, Guinea and Sierra Leone. The military intervention in Liberian conflict on 25 August 1990 marked the formal regulation of peace and security in member states, ignoring the non-interference in the internal affairs of states within the global governance and regulations of international order (Howe, 1996; Malu, 2009; Birikorang, 2013). The pertinent question to ask is, did the transformation of the securitisation strategy from peacekeeping to peace enforcement bring effective regulations of security in West Africa? If not, what are the challenges deterring ECOWAS from achieving its goals? These questions are guides to the study of ECOWAS peacekeeping and peace enforcement as strategies of regulating security threats in West Africa.

In the attempt to respond to the foregoing, the study is organized under seven headings. The first is preceded by introduction, which is a background to how ECOWAS came about in West Africa. The second is the methodology, describing the methods of data collection and analysis of the study. The third is concerned with theoretical orientation adopted for study. The fourth conceptualizes security, peacekeeping, and peace enforcement to guide the discourse. The fifth deals with how ECOWAS, transformed from economic integration into regulating security and why in West Africa. The sixth discussed the dynamics involved in governing peace and regulating regional security, and the last contains the conclusion and recommendations.

\section{Methodology}

The documentary research method has been adopted for this study to generate information necessary for investigating ECOWAS efforts in the regulation of security in West Africa, particularly how the dynamics of conflicts in member States motivated the transformation of peacekeeping operations to peace enforcement. The use of the documentary method requires a careful and systematic study and analysis of documented sources such as written texts, visual and pictorial data (Bailey, 1994; Payne \& Payne, 2004), which may be primarily based on the experience of eye-witness accounts or secondarily based on documented facts, evidence, or both (Mogalakwe, 2006; Bailey, 1994; Scott, 1990). Essentially, the data used in this study is sourced from the documented facts or evidence, a careful and systematic synthesis of data from available and reachable documents on ECOWAS and its operations in the effort to bring about sustained peaceful coexistence in West African countries as an instrument for achieving effective and profitable interstate relations.

The method of analysis adopted for this study is the qualitative method. The reason for the choice of the analytical method is motivated by the fact that the study is dealing with already documented evidences. Therefore, it requires descriptive, interpretive 
and historical techniques or approaches to achieve the purpose for engaging the study (Ahmed, 2010). The use of descriptive, interpretive and historical analytical techniques is to discover both latent and manifest contents of the data, which perhaps has not received attention but are necessary for understanding the patterns or regularities of behaviour in the study of ECOWAS peace operations in the subregion. To illuminate the study further, tables and maps are used.

\section{Toward Theoretical Underpinnings: The Regional Security Complex Theory}

The Regional Security Complex theory is adopted to study peacekeeping and peace enforcement in ECOWAS operations and the regulation of security in West Africa. The regional security complex theory was propounded in 2003 by Barry Buzan and Ole Wæver. Beyond the classical security discourse, these scholars advanced the securitization theory to include regional security, particularly how regional security complexes shape regions and the interactions within each of the regions. Barry Buzan, Ole Wæver and Jaap de Wilde (1998) argue that security concerns at the regional level relate to international security, which is about how human collectivities interact in the circumstances of perceived threats. Some of the threats and vulnerabilities could be manifest or latent in nature, which often undermines the relationship between different actors in the regions. It is in this context that Buzan (1986) viewed regional security complexes as localized sets of anarchy that mirrors the international system. In the regional sense, a set of states exists on the perceptions and concerns that their security is linked sufficiently and closely together such that it is unrealistic to state that their national security perceptions are apart from each other. This conception of security creates the atmosphere for interdependence in an intense manner, excluding a set that is external to the sets of states (Buzan, 1986; 1989). Barry Buzan and Ole Wæver (2003) put it that:

... all states in the system are to some extent enmeshed in a global web of security interdependence. But because insecurity is often associated with proximity this interdependence is far from uniform. Anarchy plus the distance effect plus geographical diversity yields a pattern of regionally-based clusters where security interdependence is markedly more intense between the states inside the complex than those outside it (p. 46).

From the foregoing, it is deducible that the regional security complex theory presents a situation where security of states is interdependent in an intrinsic pattern of common and conflicting interests, interconnected perceptions and interdependent behaviour. The interdependence is defined or conditioned by enmity and amity, rivalry rather than a shared interest, where the preponderance of threats or fears exist on a high level among states within a region (Buzan \& Wæver, 2003). In terms of enmity, regional security actors see enemy in the others, creating the tendency towards intense level of conflict formation of the region and in term of amity, even with prevailing regional con- 
flict formations, through security regime formation cooperate and mutually acceptable forms of behavior among regional security actors achieve security in their interaction, which means a community of security is formed (Buzan \& Wæver, 2003). Put differently, the conflict between two states within a region shapes the security architecture of the region, because of the preponderance of manifest or latent fears emerging from such interactions. In the context of interdependence, the security architecture of states within a region, also seen from the perspective that it is collective and congruent as such, requires the collectiveness of actions against a referent object posing threats or affecting a sector in a country within the region (Buzan \& Wæver, 2003). The purpose is to mitigate the tendency towards volatile relations. Therefore, a security threat is an ideational social construction build around the fact that security concerns are not usually distant from the region. The threat to security is the factor within the region between states, because of the intrinsic nature of security interaction between actors in the security complex (Buzan \& Wæver, 2003).

The regional security complex theory offers an understanding of the concept of security from the horizontal and vertical planes. On the horizontal plane, security is expanded to include non-military sectors such as political, economic, societal and environmental sectors while on the vertical plane and it goes beyond the state as the main actor in international relations to include individual, social groups and humanity as a whole. Both the horizontal plane and vertical plane have the capacity to shape the security architecture of a region, to motivate security interdependence among different actors within the region to respond to the challenges (Buzan \& Wæver, 2003). Security complexes exist geographically, but not necessarily between or among states, though a majority of these complexes exist within states in a region, which poses a security threat to the security of other states within the region. Therefore, adopting the strict criteria for defining a security complex becomes problematic because security complexes are understood from the geographical proximity of actors whose security interacts, acted upon by force internal to the region due to the rivalry between two or more actors (Buzan, 1991). In this context, a region is a subsystem that is distinct and significant in terms of security relations, which exist between a set of states closely locked geographically and are proximate to one another (Buzan, 1991; Buzan \& Wæver, 2003).

Applying the theoretical construct to ECOWAS, it presents the supranational organisation as existing on a security complex composed of states in the West African subregion. However, the supranational organisation motivated by shared interests rather than rivalry became a major interest of ECOWAS. Therefore, interdependence in terms of securitization of member states is clearer. The characters of the states as major actors in ECOWAS are conditioned by a rule-governed practice defined, determined and directed by the charter governing ECOWAS which they collectively admitted (Balzacq, 2005; Bah, 2005). Contravening ECOWAS-rule governed practices attracts sanctions, 
suspension or both. Also, in the case of the internal security threat posed to a member state, other member states intervene taking into consideration the basic principles governing peacekeeping (Jaye \& Garuba, 2011). The goal is to make peace and restore security of life and property. Where peacekeeping fails, peace enforcement takes effect using the military to de-escalate the conflicting relation in a member state or between member states because if they do not intervene, such situation could generate security complexes that may undermine the basis of economic integration and development in West Africa (Bah, 2005; Arthur, 2010).

\section{Security, Peacekeeping and Peace Enforcement}

The recurrences of events in Africa, particularly in West Africa, are of security, peacekeeping and peace enforcement implications. The concept of security, peacekeeping and peace enforcement are therefore contextual and cannot be neglected. Security is an embracing phenomenon that has direct implications on the security of the state, being a very important issue in the survival of any country. There is the tendency of lawlessness to occur, rendering insecure the lives and property of the people. Security is polymorphic in approach, meaning it can take the form of a military, ideological, economic or cultural approach (Wæver, 1997; 2000). Central to security are law and order as essential needs for the society to work smoothly and effectively in a way that no segment of the society is worse-off.

Security is a social construct (Baldwin, 1997), which is associated with an illocutionary speech act, which by pronouncement or by labelling a phenomenon, becomes a security issue (Wæver, 1995; 1997). However, security goes beyond the speech act of labelling a phenomenon as a security issue. Thierry Balzacq (2005) argued that security is audience-centered, context-dependent and power-laden before it becomes a security issue that requires intervention. Notwithstanding, McGrew (1988:101) puts it that security is about maintenance of peace and protection of the socioeconomic order from internal and external threats, as well as promoting international and domestic order that minimises the threat to widely-held core-values and interest. Security is holistic because it encompasses both state and humanistic points of view about security of life and property in any society (Baldwin, 1997). From the state point of view, security has entailed securing the sovereignty of the state from internal insurrection and external aggression using the instruments of aggression and, from a humanistic point of view, it entails securing the people from outside assaults as well as from decimating outcomes of inside changes, unemployment, hunger, starvation, sicknesses, numbness, vagrancy, ecological corruption and contamination with financial shameful acts (Nwolise, 2006; Wæver, 2000).

The security of lives and property requires the conceptual mechanism to situate and deal with security concerns appropriately. These security concerns also require securitiza- 
tion, which informs the "process through which an inter-subjective understanding is constructed within a political community to treat something as an existential threat to valued referent object and to enable a call for urgent and exceptional measures to deal with the threat" (Buzan \& Wæver, 2003, p. 491). Security challenges and securitization of the political community led to the development of concepts such as peacekeeping and peace enforcement. These two concepts have often been used interchangeably, but they are not the same. Peacekeeping is a technique designed purportedly to make sure peace returns in previously hostile society. It involves the use of military, police and civilian primarily as a model of observing cease-fire among the belligerents. The role of the peace-keepers is to create the conditions that bring about prevention of hostility between and among parties in conflict. Central to peacekeeping is the mutual observance of the rights and freedom of the people while working to help make sure the lasting peaceful relations in war-ravaged countries are returned and or sustained (de Coning, Aoi \& Karlsrud, 2017).

Peacekeeping efforts precede peace enforcement. Peace enforcement comes about when peacekeeping fails to make the goals set out to bring the parties in conflict to the point of restraint. Peace enforcement, therefore, is about the use of a range of coercion methods, including the military force, particularly when there is a threat or a breach of peace or aggression (de Coning, Aoi \& Karlsrud, 2017). ${ }^{1}$ Peace enforcement, as a technique, is designed to end hostility and, before it comes into operation, the Security Council must approve of it, given that the conditions surrounding the relationship between parties in conflict is becoming or has become precarious and, above all, there is violation of human rights and freedom of the people (de Coning, 2017). ${ }^{2}$ The purpose is to dispel existential threats to life and property, which is feared to have effect on or the tendency of spilling over other states in the subregion. But before peacekeeping or peace enforcement is adopted, there must be a designated existential threat justified and a requirement for extraordinary measure to handle it (Wæver, 1995, p. 55). Security, peacekeeping and peace enforcement are integral to ECOWAS regulation of security in West Africa and are foundational to achieving economic growth and development through trade relations.

\section{ECOWAS: From Economic Integration to Regulations of Security in West Africa}

The reinvigorating support by Eyadema and Gowon for establishing ECOWAS was motivated by several reasons. To Eyedema, there was the need to set up a supranational organisation capable of achieving the collective goal of making the West Africa economically self-sufficient through a single bloc that would be a rallying point for trade among member states (Agbo, 2003). This understanding hinges on the fact that no country can attain self-sufficiency without relying on the other. Specifically, from the Gowon point of view, the supranational organisation was to secure the regulations of security in the West African subregion from external influence, especially from France, considering her 
role in the Nigeria-Biafra civil war. During the Nigeria-Biafra civil war, it was assumed that France had sympathy for the secessionist movement of the Igbo people in Nigeria to form Biafra (Agbo, 2003). This concern over security precariousness of states in the immediate postcolonial societies, particularly in the West Africa, motivated the need of establishing an integration supranational organization to mediate security challenges faced by member states by not allowing foreign powers to interfere with the security matters in, as well as enhancing economic integration of West Africa. The protocol of ECOWAS was signed by sixteen countries (see table 1), a set of contiguous countries, bordered to the south and west by the Atlantic Ocean and to the north by the Sahara Desert (see figure 1).

Table 1: ECOWAS Member States

\begin{tabular}{|c|c|c|c|}
\hline 1 & 28 May 1975 & Benin & Full Member \\
\hline 2 & 28 May 1975 & Burkina Faso & Full Member \\
\hline 3 & 28 May 1975 & Cote d'Ivoire & Full Member \\
\hline 4 & 28 May 1975 & Gambia & Full Member \\
\hline 5 & 28 May 1975 & Ghana & Full Member \\
\hline 6 & 28 May 1975 & Guinea-Bissau & Full Member \\
\hline 7 & 28 May 1975 & Liberia & Full Member \\
\hline 8 & 28 May 1975 & Mali & Full Member \\
\hline 9 & 28 May 1975 & Nigeria & Full Member \\
\hline 10 & 28 May 1975 & Senegal & Full Member \\
\hline 11 & 28 May 1975 & Sierra Leone & Full Member \\
\hline 12 & 28 May 1975 & Togo & Full Member \\
\hline 13 & 28 May 1975 & Mauritania & Full Member* \\
\hline 14 & 28 May 1975 & Guinea & Full Member** \\
\hline 15 & 28 May 1975 & Niger & Full Member** \\
\hline 16 & 1977 & Cape Verde & Full Member \\
\hline
\end{tabular}

* In 2002 Mauritania withdrew membership from the community.

** Guinea was suspended after the 2008 coup d'état; Niger also was suspended after the 2009 coup d'état.

Source: www.internationaldemocracywatch.org/ index.php/economic-community-of-west-african-states-

Since its establishment, ECOWAS has become one single formidable force in not only promoting economic integration but also in mitigating security challenges among member states in West Africa. The principal goal of ECOWAS was economic integration expanded to include food and agriculture, industry, science and technology, energy, environment and natural resources, transport, communication and tourism, trade, customs, taxation, statistics, money and payments, and political, judicial and legal affairs, regional security and immigration, among other areas. The scope of interest and operation of ECOWAS, as noted in the revised treaty signed at Cotonou, the Republic of Benin on the 24 July 




Figure 1: Map of West Africa

Source: Maps of World, www.mapsofworld.com/africa/regions/western-africa-map.html

1993, was indicative that the supranational organization was more than just an economic integration organization, but a one that is also interested in the security of West Africa (Jaye \& Garuba, 2011). The need to meet the many goals set out by ECOWAS as essentials for economic integration of the subregion led to establishing ECOWAS Ceasefire Monitoring and Observer Group (ECOMOG).

\section{ECOWAS: Governing Peace and the Regulation of Regional Security in West Africa}

The West African sub region has remained over the years one of the security complexes in Africa since the 1990s, constituting major challenges to realising the objectives of ECOWAS. The effort to tame the monster of conflicting relations in West Africa, led to the establishment of ECOWAS Cease-fire Monitoring and Observer Group (ECOMOG) established in 1990. The ECOMOG is ad-hoc body saddled with the responsibility of regulating peace and security in West Africa subregion. ${ }^{3}$ The Librarian crisis made ECOWAS member states to discover that economic integration and development can only be achieved in an environment of peace and security. As Tagowa (2007:106) observed, it was amidst contradictions and poor performance that ECOWAS transformed into a political security outfit. The ECOWAS mediation, peacekeeping and peace enforcement in Liberia, Sierra-Leone, Guinea Bissau and Cote d'Ivoire were testimonies of insecurity in West African subregion (Integrated Regional Information Network for West Africa, 1998; Emuekpere, 2015). The dynamics of global govern- 
ance and regulations which have been unfavourable to Africa, before and after Cold War era, changed the focus of ECOWAS from merely economic integration to peace and security governance. Some of the security governance interventions of ECOWAS through ECOMOG are in table 2.

Table 2: ECOWAS Peace and Security Interventions in West Africa

\begin{tabular}{cl}
\hline Period & \multicolumn{1}{c}{ Some ECOWAS Intervention in Peace and Security Governance } \\
\hline 1990 & Intervenes in Liberian civil war; presence peaks at 12,000 troops \\
\hline 1997 & Election of Charles Taylor as Liberian president marks the culmination of Liberian mission. \\
1997 & $\begin{array}{l}\text { ECOWAS deployed large-scale force in Sierra Leone after rebels overthrow President Kabbah, } \\
\text { and to prevent the Revolutionary United Front (RUF) from overrunning the state. }\end{array}$ \\
1998 & Drives rebels from Sierra Leone capital reinstates Kabbah as president. \\
1999 & $\begin{array}{l}\text { Deploys peacekeepers in Guinea-Bissau after armed conflict between the president and rebel } \\
\text { military chief. }\end{array}$ \\
\hline 1999 & $\begin{array}{l}\text { Recaptures Sierra Leone capital Freetown after the guerrilla offensive } \\
2001\end{array}$ Stations troops on Guinea-Liberia border to stop guerrilla infiltration. \\
2002 & $\begin{array}{l}\text { ECOWAS intervened in Cote d'Ivoire crisis and help negotiate the process that led to the res- } \\
\text { toration of peace. }\end{array}$ \\
2003 & $\begin{array}{l}\text { ECOWAS launched a peacekeeping mission named ECOMIL to halt the occupation of Monrovia } \\
\text { by the rebel force to ensure transition to democracy was successful. }\end{array}$ \\
& $\begin{array}{l}\text { ECOWAS showed strong political will in providing leadership to solve the problem and in nego- } \\
\text { tiating the Framework Agreement of } 6 \text { April 2012that help Mali to resolve its security, political } \\
\text { and institutional crises. }\end{array}$ \\
\hline 2017 ECOWAS restates demonstrated commitment to peace, security and democracy in the Gambia. \\
\hline
\end{tabular}

Sources: Economic Community of West African States (ECOWAS), www.ecowas.int/ecowasrestates-commitment-to-peace-security-and-democracy-in-the-gambia/; BBC News, Profiling ECOMOG, http://news.bbc.co.uk/1/hi/world/africa/country_profiles/2364029.stm, Jibrin Ibrahim (2014) The Malian Crisis: West Africa and the Hegemons, February 10, www.premi umtimesng.com/opinion/154954-malian-crisis-west-africa-hegemons-jibrin-ibrahim.html.

The enormities of conflicts in the subregion were far-reaching effects of the disequilibrium in the global governance system, which favours the centres of capitalism more than the periphery. The post Cold War global governance and regulation as in other third world states left states in the West African subregion with no option, but to adopt capitalism and harsh economic policies. The capitalist system weakened states in Africa and forcefully pushed for reforms that were detrimental to the human security in Africa. Across West Africa, elected governments had to stick to the implementation of unpopular International Monetary Fund (IMF) and World Bank's Structural Adjustments Programmes (SAP) that brought a severe impact on the working and living conditions of the majority of the populace (Olukoshi, 2001). This situation created "armies in waiting" in most states in West Africa, ready to be manipulated by the political class. The response to the situation by the various states took away their interest from human security and re-defined the context of national security to mean the protection of the 
regime in power. This situation in 1980s led to several violent conflicts that lasted for over two decades in some West African states.

The ECOWAS security architecture, the ECOMOG, operated in a manner that responded to the need of protecting life and property of the people and ensuring an atmosphere of relative peace in which they can pursue lawful activities (Horsfall, 1991, p. 7). With such unprecedented large scale involvement of civilians in armed conflict, it became clear that security discourse in ECOWAS had to evolve beyond its statist conceptions and assumptions. It was in this context that ECOWAS revised its treaty in 1993 (Horsfall, 1991, p. 7). ${ }^{4}$ The revised treaty signalled a departure from an approach in which the old authoritarian regimes accepted as normal and emphasised democracy and rule of law as frameworks in which the economic integration and development agenda should be pursued. The frameworks now form the core of the ECOWAS peace and security architecture. The ECOWAS intervention in the Liberian conflicts marked the watershed in the peacekeeping operation in West Africa. Liberia was the testing ground for ECOMOG, which shifted from peacekeeping to peace enforcement due to the conflict. Majority of the ECOWAS member state saw the Liberian conflict as a regional security challenge because of its tendency of spilling over into other countries in West Africa, hence the need to intervene. ECOMOG restored stability and enabled democracy to thrive in Liberia (Obi, 2009).

The ECOMOG has executed peacekeeping operations in other countries and has contributed heavily to the peace and security of the subregion (Human Rights Watch, 1993; Integrated Regional Information Network for West Africa, 1998). Therefore, the relative stability in the security complexes in West Africa can be attributed to the role of the ECOMOG (Pitts, 1999). It is noteworthy that for ECOWAS to achieve its goals of economic integration, the principle of non-interference in the internal affairs of sovereign states was ignored. That was the first time when a near-genocide has taken place in the Mano River region (Birikorang, 2013; Osadolor, 2011). The big states in ECOWAS helped, by using the supranational institution to regulate security challenges in small states considered to have a negative impact in the subregion. There is no doubt that ECOWAS security architecture has been commendable at more than one point - putting warring groups to a cease-fire, ensuring that parties in conflict do not negate the principles governing war and the protection of non-combatants and the supervision of transitions to democracy in the subregion (Obi, 2009; Maiangwa, 2015; Okere, 2015).

\section{ECOWAS and the Challenges of Regulation of Regional Security in West Africa}

The ECOWAS efforts in peacekeeping and peace enforcement have not been without challenges. The coordination of ECOWAS in peacekeeping and peace enforcement operations cover a wide range of territorial space that has poor transport and communication 
networks with several patterns of conflict dynamics across the states in West Africa. The pattern of the conflicts in the West African subregion also motivated the changes in the pattern of ECOWAS security governance from peacekeeping to peace enforcement.

The ECOWAS interventions in Liberia and Sierra-Leone marked the beginning of peace enforcement in entirely different ways. Before the conflicts in the Mano River region, the pattern of ECOWAS security governance has been on an ad-hoc basis or sealed in protocols (Adebajo \& Adebajo, 2002; Integrated Regional Information Network for West Africa, 1998). These protocols framed the perceptions and responses to security challenges along external threats. For instance, the 1978 protocol on non-aggression signed in Lagos and the 1981 protocol relating to Mutual Assistance on Defense signed in Freetown was based on the aforesaid prevailing security thinking of externalities of threats (Osadolor, 2011; Kabia, 2009). The post-Cold War security threats are more internal to West Africa because of the predominant use of small and light weapons among different ethnic groups, rendering the conflicts in the region highly intractable and far-reaching in terms of humanitarian consequences (Malu, 2003). These dynamics showed that ECOWAS misjudged the nature of the security challenges confronting West Africa (Ukeje, 2015; Howe, 1996).

The new challenges of security governance in the subregion which most states are facing in West Africa informed the reason for ECOWAS not preferring to regard internal conflicts as internal affairs of member states. The Mano River region conflicts no doubt challenged ECOWAS to re-examine its security mechanism and ignore the noninterference in internal affairs of states doctrine by deploying the first contingents of the ECOMOG military intervention to bring peace and security to Liberia in the 1990s (Adebajo \& Adebajo, 2002; Kabia, 2009). The level of violence in Liberia involving the ragtag military operation that had no regards for human rights with accompanied abuses of the rules governing war, led ECOMOG to change its mode of operation to peace enforcement (Kabia, 2009; Engel \& Gomes, 2016). Despite the fact that the import of peace enforcement under the Nigerian leadership of ECOMOG was treated with suspicion, militarization appeared necessary to contain both real and potential violent threats to life and property in the region, its very nature becoming a threat to peace and notions of sovereignty and independence (Iwilade \& Agbo, 2012).

Another challenge ECOWAS is confronted with is the polarisation of member states along colonial history, which greatly undermines its capabilities of countering security challenges that the subregion faces. The impact of colonialism affects the effectiveness of ECOWAS, in that the division along Francophone, Anglophone and Losophone identities creates division among the Heads of States and Governments of member states, making it difficult for the supranational organisation to achieve a common front for West Africa. The differences in colonial history and languages in West Africa further influence the different patterns of ideological orientation of member states also because the Heads of 
States and Governments of ECOWAS are more disposed, sympathetic and passionate to issues and resolutions that affect their own people. The implication is mutual suspicion and distrust, which creates tension between some of the states (Iwilade \& Agbo, 2012). The most disturbing aspect is that the majority if not all the Francophone countries have a French military base in their states, which France often uses to maintain authoritarian regimes that pledge loyalty to Paris in the subregion. The case of Cote d'Ivoire Crisis is an example (Kabia, 2009). Even though ECOWAS responded quite robustly to the changing security complexes in West Africa, it has yet to develop the capacity to effectively respond to the various conflict dynamics in the subregion.

The ECOWAS still depends significantly on the logistical support of the international community, particularly of the Western countries, for peacekeeping and peace enforcement operations. The support otherwise provided by the United Nations and France has had serious implications on the legitimacy of ECOWAS peacekeeping mission in the recent Cote d'Ivoire crisis (Obi, 2009; Maiangwa, 2015). Nevertheless, ECOWAS also depend on the willingness of regional hegemonic countries like Nigeria to take the burden of the political, military and financial costs of peacekeeping or peace-enforcing in the subregion (Iwilade \& Agbo, 2012).

It also follows that Nigeria is confronted with the Boko Haram insurgency, which constrains its support for ECOWAS in responding to the West African security complexes (Maiangwa, 2015). Furthermore, one of the most silent but potent challenges of ECOWAS are institutional and democratic deficits. The institutions that sustain democracy are very weak in ECOWAS member states. Such weaknesses provide the avenues for authoritarianism in member states, and the implications are agitations and confrontations by marginalized and disenchanted groups against the state, which in most instances transforms into civil conflicts. Democracy in most states has not strengthened institutional mechanisms capable of preventing that large-scale conflicts in West Africa. It explains the inability of ECOWAS to effectively confront the authoritarian currents that continue to run deep in West Africa. These challenges render ECOWAS as Jallow (2015) described, "an arena of mediocrity and dysfunction" in contemporary times. Despite the challenges, ECOWAS has significantly attenuated the effects of violence across other states in the subregion (Bah, 2005; Arthur, 2010). ECOWAS has the opportunity to improve on its capabilities in navigating between the principles of economic integration and development and the peacekeeping and peace enforcement operations in West Africa.

\section{Conclusion and Recommendations}

This study was set out to respond to the pertinent question of did the transformation of the securitisation strategy from peacekeeping to peace enforcement bring effective regulations of security in West Africa? If not, what are the challenges deterring ECOWAS from achieving its goals? The study revealed that ECOMOG is a mechanism adopted by ECOWAS in the 
face of excruciating security challenges that have undermined its goals of economic integration and development. Particularly from the 1990s, West Africa experienced several internal conflicting relations among member states. There was the understanding that ECOWAS countries could not have engaged member states in meaningful and profitable relationship necessary for economic integration and development in an atmosphere heralded by insecurity, hence the adoption of ECOMOG as a mechanism to keep and enforce peace and security in West Africa. The ECOMOG initially had monitoring and observatory roles in peacekeeping operations as a way of fostering peace and security in West Africa. The circumstances that surrounded the conflicts in most states in West Africa and beyond were not only violent but near-genocidal in nature, particularly the Liberian conflict in the 1990s. That also motivated the transformation of peacekeeping operations into peace enforcement, which mitigated and transformed the violent atmosphere to negotiate for peace and stability that returned the country to democracy. The ECOWAS, as a supranational organisation building on the interdependence of security architecture, despite the enormity of challenges, has contributed in mitigating security threats and fostering peace and security in West Africa. However, there is still much to be desired of ECOWAS within the security complexes of West Africa.

In order to improve on the ECOWAS capabilities, the regulations of peace and security should begin from the perspectives of the people after the culmination of the peacekeeping operation. ECOMOG has been celebrated as ECOWAS efforts to guarantee peace and security in the subregion, but the fact remains that the conflicts that engulfed ECOWAS member states were caused by the economic conditions of the people which the state failed to address. In this context, it is pertinent to state that ECOWAS has not done excellently, because goals of economic integration and development have not, in most parts of West Africa, resulted in the empowerment of the poor population. Economic integration and development are largely rhetoric yet to be realised in concrete terms. If economic integration would have been realistic, it would have saved ECOWAS the enormity of conflicts in West Africa in contemporary times.

Nevertheless, ECOWAS should learn from the EU. The first task for new members is to work on their internal democratic institutional frameworks, governance and economic systems to measure up with the standard required before admitting them into ECOWAS. Therefore, the regulatory mechanism for peace and security in ECOWAS should start with the member states. ECOWAS must influence member states to intensify their efforts to improve democracy in their respective countries, because the majority of the democracies in the subregion reflect the political character of postcolonial states (Alavi, 1973), with prevalence of coloniality of power masquerading as democracy, thereby fuelling conflicts in most countries within the West African security complex.

Again, the internal regulatory agencies and institutions of member states are all colonially inherited and are still used by the political elites without reducing their oppressive 
and repressive contents. What this means is that the regulatory agencies and institutions in most member states are meant only to protect the regime in power, not directed towards providing human security. The ECOWAS should encourage member states to work on their regulatory agencies and other institutions, whose weaknesses form the basis for the insecurity in the subregion and the reason for which peace enforcement efforts are deployed. The securitisation of West Africa and its economic integration and development strategies depend on ECOWAS' ability to make member states pass a test of internal democracy modelled after the EU, which has institutional building that enhances democratic consolidation, the rooted nature of the rule of law and the protection of fundamental human rights of the people, as well as the respect for and protection of the minorities as cardinal requirements for admission into the EU. Without reaching these requirements, ECOWAS' goals will not be attained.

\section{Notes:}

1 See, GlobalSecurity.org, www.globalsecurity.org/military/library/report/call/call_93-8_chap3.htm.

2 See United Nations Peacekeeping, Peace and security, www.un.org/en/peacekeeping/operations/ peace.shtml

3 See, Profile: ECOMOG. Nigerian soldier in Sierra Leone, 1999 Nigerian troops form the backbone of the peacekeeping force, BBC News (2004) The bloody civil war in Liberia prompted the Economic Community of West African States (ECOWAS) to set up an armed Monitoring Group - ECOMOG for short - in 1990. http://news.bbc.co.uk/1/hi/world/africa/country_profiles/2364029.stm; also see ECOWAS Standing Mediation Committee (SMC) (1990) Decision-A/Dec 1/8/90 on the Cease-Fire and Establishment of ECOMOG, For Liberia Banjul, 7 August.

4 See, the ECOWAS Treaty signed in Cotonou on 24 July 1993.

\section{References:}

1. Adebajo, A., \& Adebajo, A, (2002). Liberia's Civil War: Nigeria, ECOMOG, and Regional Security in West Africa; Building Peace in West Africa: Liberia, Sierra Leone, and GuineaBissau. Boulder, CO.: Lynne Rienner Publishers.

2. Agbo, U. J. (2003). ECOWAS and the European Union: A Comparative Study of Regional Integration. M.Sc. Thesis, Department of Political Science, Ahmadu Bello University, Zaria.

3. Ahmed, J. U. (2010). Documentary Research Method: New Dimensions. Indus Journal of Management \& Social Sciences, 4(1), 1-14.

4. Arthur, P. (2010). ECOWAS and Regional Peacekeeping Integration in West Africa: Lessons for the Future. Africa Today, 57(2), 3-24.

5. Bah, S.M. (2004). ECOWAS and the Dynamics of Constructing a Security Regime in West Africa. Kingston: Canadian Queens University.

6. Bah, S.M. (2005). West Africa: From a Security Complex to a Security Community. African Security Review, 14(2), 77-88.

7. Bailey, K. D. (1994). Methods of Social Research. New York: The Free Press.

8. Baldwin, D. (1997). The Concept of Security. Review of International Studies, 23(1), 5-26. 
9. Balzacq, T. (2005). The Three Faces of Securitization: Political Agency, Audience and Context. European Journal of International Relations, 11(2), 171-201. DOI: https://doi. org/10.1177/1354066105052960.

10. BBC (2004, June 17). Profiling ECOMOG. BBC News. Retrieved from http://news.bbc. co.uk/1/hi/world/africa/country_profiles/2364029.stm.

11. Birikorang, E. (2013). Lesson Learned and Best Practice from a Troubled Region: ECOWAS and the Development of ECOWAS Standby Force. In E. Ulf and J. Gomes (Eds.). Towards an African Peace and Security Regime: Continental Embeddedness, Transnational Linkages, Strategies Relevance (pp. 89-110). New York: Routledge Publishers.

12. Buzan, B. (1986). A Framework for Regional Security Analysis. In B. Buzan and G. Rizvi (Eds.), South Asian Insecurity and the Great Powers (pp. 3-33). London: Croom Helm.

13. Buzan, B. (1989). Regional Security. Arbejdspapirer, no. 28. Copenhagen: Centre for Peace and Conflict Research.

14. Buzan, B. (1991). People, States and Fear. Harvester Wheatsheaf.

15. Buzan, B., \& Wæver, O. (2003). Regions and Powers: The Structure of International Security. Cambridge: Cambridge University Press.

16. Buzan, B., Wæver, O., \& de Wilde, J. (1998). Security: A New Framework for Analysis. Boulder: Lynne Rienner Publishers.

17. de Coning, C. (2017). Peace Enforcement in Africa: Doctrinal Distinctions between the African Union and United Nations. Journal Contemporary Security Policy, 38(1) 145-160.

18. de Coning, C., Aoi, C., \& Karlsrud, J. (2017). UN Peacekeeping Doctrine in a New Era: Adapting to Stabilisation, Protection and New Threats. New York: Routledge.

19. Emuekpere, P. (2015). ECOWAS of States or ECOWAS of People. Development Monitor, No 28.

20. Engel, U., \& Gomes, J. (2006). Towards an African Peace and Security Regime: Continental Embeddedness, Transnational Linkages, Strategies Relevance. New York: Routledge Publishers.

21. Horsfall, A. K. (1991). Brief on National Security. In State of the Nation. Policy Briefs for Politicians. Bwari-Abuja: Centre for Democratic Studies (CDS).

22. Howe, H. (1996). Lessons of Liberia: ECOMOG and Regional Peacekeeping. International Security, 21(3), 145-176.

23. Human Rights Watch/Africa, Liberia (1993). Waging the War to Keep the Peace: The ECOMOG Intervention and Human Rights. Human Rights Watch, 5(6).

24. Integrated Regional Information Network for West Africa (1998) IRIN-West Africa Background Briefing on ECOMOG. Relief Web. Retrieved from http://reliefweb.int/report/liberia/irin-west-africa-background-briefing-ecomog.

25. Iwilade, A., \& Agbo, U. J. (2012). ECOWAS and the Regulation of Regional Peace and Security. Democracy and Security, 8(4), 358-373.

26. Jallow, M. (2015). ECOWAS, an Arena of Mediocrity and Dysfunction. Development Monitor, No. 28.

27. Jaye, T., \& Garuba, D. (2011). ECOWAS and the Dynamics of Conflict and Peace-Building. Dakar: CODESRIA. 
28. Kabia, J. M. (2009). Humanitarian Intervention and Conflict Resolution in West Africa: From ECOMOG to ECOMIL. London and New York: Routledge Publishers.

29. Khobe, M. M. (2000). The Evolution and Conduct of ECOMOG Operations in West Africa. Monograph No. 44: Boundaries of peace support operations.

30. Maiangwa, B. (2015). Assessing the Response of the Economic Community of West African States to Recurring and Emerging Security Threats in West Africa. Journal of Asian and African Studies, 52(1), 1-8.

31. Malu, L. (2003). Collective Peacekeeping in West Africa. Peace \& Conflict Monitor. Retrieved from www.monitor.upeace.org/archive.cfm?id_article=61.

32. Malu, L. (2009). Background Note on ECOWAS. Background Note: World Bank Headline Seminar on the Global and Regional Dimensions of Conflict \& Peacebuilding, Addis Ababa, October 10 \& 12 .

33. McGrew, T. (1988). Security and Order: The Military Dimension. In M. Smith, S. Smith and B. White (Eds.), British Foreign Policy: Tradition, Change and Transformation (pp. 99-123). London: Unwin Hyman.

34. Mogalakwe, M. (2006). The Use of Documentary Research Methods in Social Research. African Sociological Review, 10(1), 221-230.

35. Nwolise, O. B. (2006). National Security and Sustainable Democracy. In E. O. Ojo (Ed.) Challenges of Sustainable Democracy in Nigeria (pp. 347-355). Nigeria: Ibadan: John Archer Publishers.

36. Obi, C. I. (2009). Economic Community of West African States on the Ground: Comparing Peacekeeping in Liberia, Sierra Leone, Guinea-Bissau, and Cote-d'Ivoire. African Security, 2, 119-135.

37. Okere, L. I. (2015). ECOWAS Conflict Management and Peacekeeping Initiatives in West Africa. Journal of Law, Policy and Globalization, 37, 30-45.

38. Olukoshi, A. (2001). West Africa Political Economy in the West Millennium: Retrospect and Prospect. Monograph. Dakar: Council for Development of Social Science Research in Africa (CODESRIA).

39. Osadolor, O. B. (2011). The Evolution of Policy on Security and Defence in ECOWAS, 1978-2008. Journal of the Historical Society of Nigeria, 20, 87-103.

40. Payne, G., \& Payne, J. (2004). Key Concepts in Social Research. London: Sage Publications.

41. Pitts, M. (1999). Sub-Regional Solutions for African Conflict: The ECOMOG Experiment. The Journal of Conflict Studies, 29(1), 39-59.

42. Scott, J. (1990). A Matter of Record: Documentary Sources in Social Research. Cambridge, UK: Polity Press.

43. Tagowa, W, N. (2007). Sociological Approach to the Study of International Organization. Journal of law and international security, 1(2). Ekpoma: Department of Public Law, Ambrose Alli University.

44. Ukeje, Ch. (2015). From Economic Cooperation to Collective Security: ECOWAS and the Changing Imperatives of Sub-Regionalism in West Africa. In W. Fawole and C. Ukeje 
(Eds.) The Crisis of the State and Regionalism in West Africa: Identity, Citizenship and Conflicts (pp. 133-153). Dakar: CODESRIA Book Series.

45. Wæver, O. (1995). Securitisation and Desecuritisation. In R. Lipschutz (Ed.) On Security (pp. 46-86). New York: Columbia University Press.

46. Wæver, 0. (1997). Concept of Security. Copenhagen: Institute of Political Science, University of Copenhagen.

47. Wæver, O. (2000). What is Security? - The Securityness of Security. In B. Hansen (Ed.) European Security Identities (pp. 222-255). Copenhagen: Copenhagen Political Studies Press. 